\title{
AL-BADEE OF ABU AL-HASAN AL-HUSARI AL-QAYRAWANI IMPACT IN DEVELOPING OF THE ARGUMENTATION STUDY
}

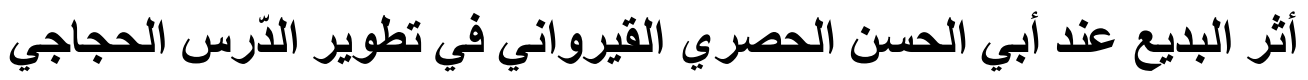

Sekou KOUYATE

King Saud University, Riyadh, Saudi Arabia

jelifama@gmail.com

\begin{abstract}
The research aims to reinterpret the well-known of Al-Badee Arts, in view of the Argumentation theory, in order to observe the transformations of the meaning in some models of Poetry of Abu Al-Hasan Al-Husari Al-Qayrawani. The researcher used the applied descriptive method, to study the ways of the transformations of the meaning, and extracting some models from the poems, and analyzing them. Therefore the research reached some important conclusions which are;1) If the new rhetoric is interested in the embellishment, because it is an Important instrument to the creativeness and the persuasion, Al-Badee can develop the Argumentation study, especially if the poet is sincere in his sufferance, and also wishes to convey his message, such as Al-Husari who benefited from Al-Badee Arts, for the purpose of persuasion, proof, and inference, 2) The poet was able to combine between the form and content. His interests in Al-Badee Arts revealed his desire to remove dust from speech, and give it the complete clarification, customization and justification, etc., generally, his employment of Al-Badde fits the meaning he is trying to form, 3) The repetition of the poet for some elements isn't a proof of inability to apply others elements, or a desire to decorate the speech only, but because he was bound by this repetition for its influential importance.
\end{abstract}

Keywords: Al-Badee, Argumentation theory, Meaning

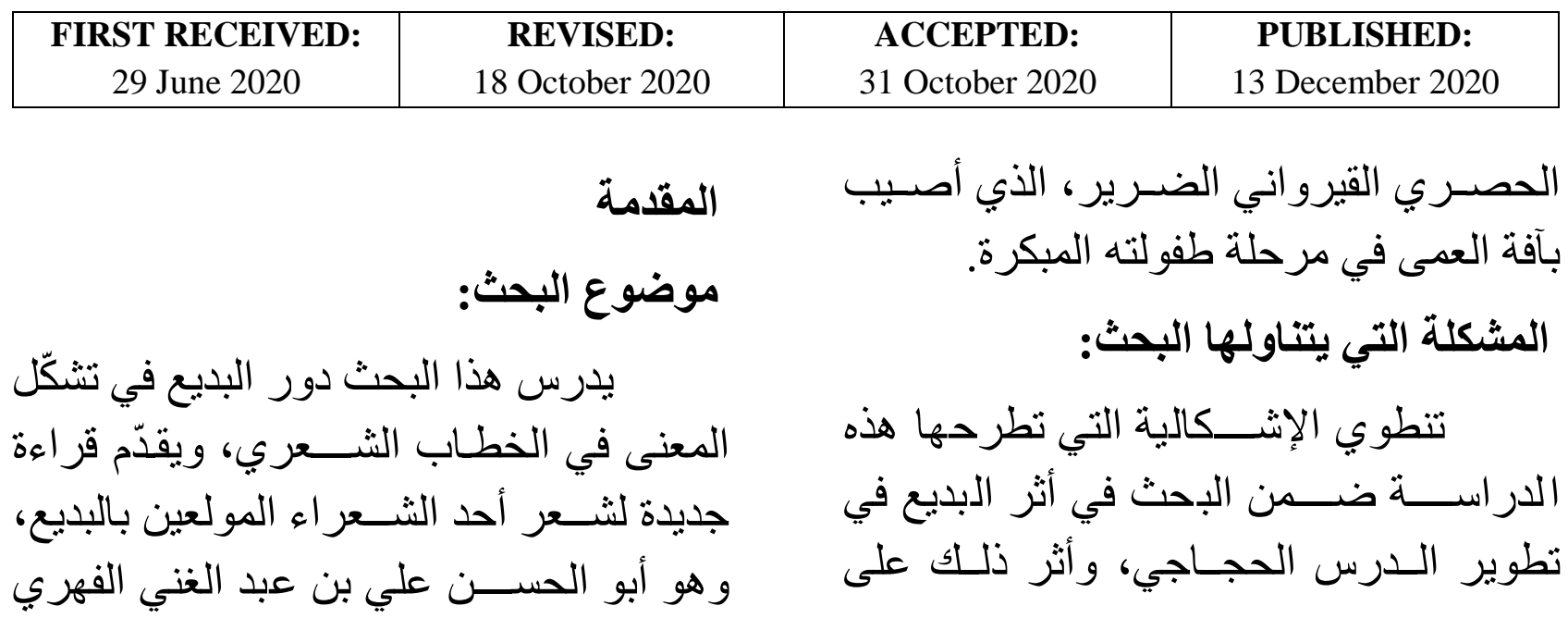

Al-Badee Of Abu Al-Hasan Al-Husari Al-Qayrawani Impact In Developing Of The Argumentation Study 
المتلقي، إن البحـث في العلاقـة بين البـديع

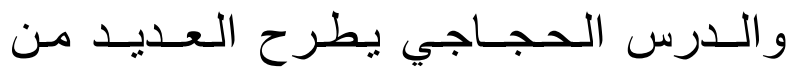

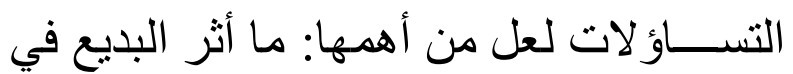

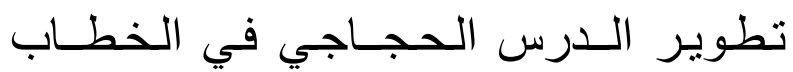

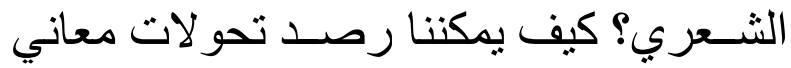

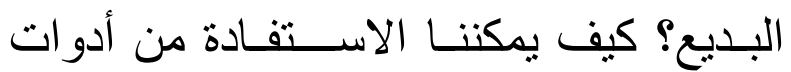

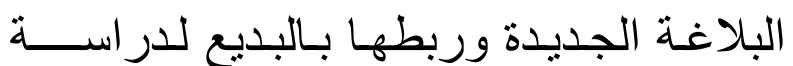
ظاهرة الحجاج؟ تساؤلات البحث:

يســـى البحث إلى الإجابة عن عدد من الأسئلة منها: - البئ

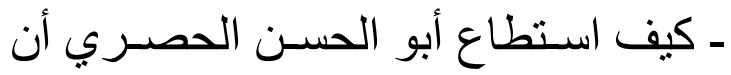
يوفّق بين الاهنمام بالثكل و المضمون؟

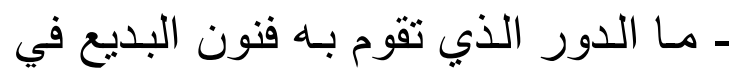

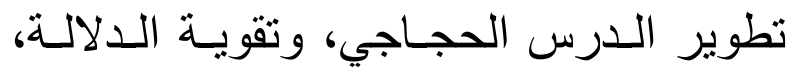

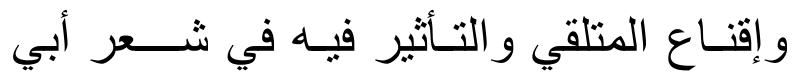
الحسن الحصري؟

\section{منهج البحث:}

اسـتخدم الباحث المنهج الوصـي التطبيقي

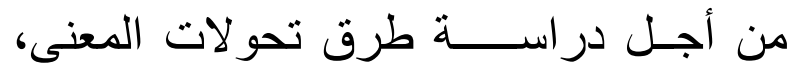

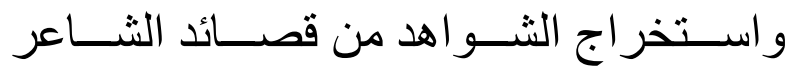
وتحليلها، وذللك من أجل الوقوف على أثر هذا اللون البلاغي في تطوير الدرس الحجاجي.

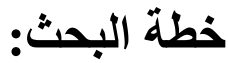
و يتكون هـذا البحـث من تمهيـد،

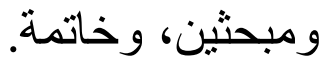

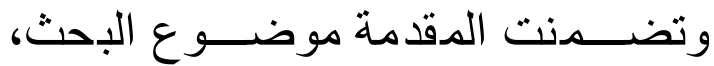

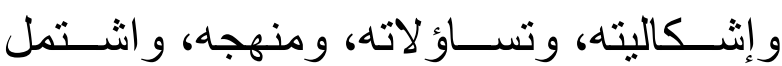

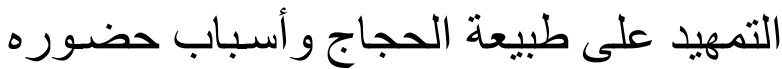

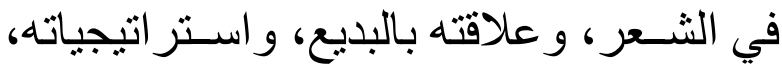

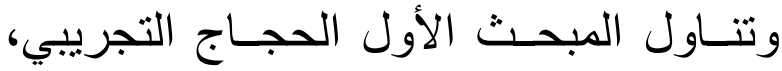

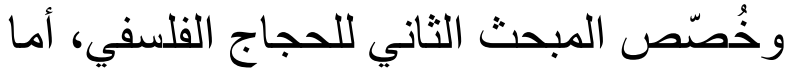
الخاتمة فاثـــتملت على أهم النتائج، و قائمة المصادر و المر اجع. الكلمات المفتاحية: البديع، المعنى، ولهر، نظرية الحجاج.

\section{التمهيد}

أولا: طبيعة الخطاب الحجاجي وأسباب حضوره في الشعر، وعلاقته بالبديع:

لقـد قـام القـدامى بـالتمييز بين الثــــر

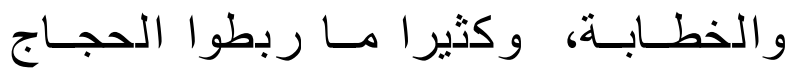

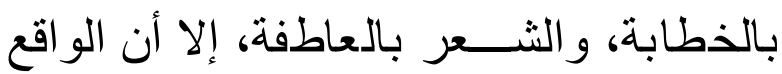

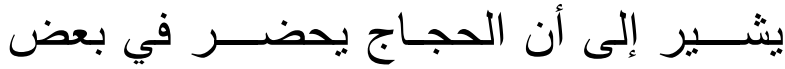

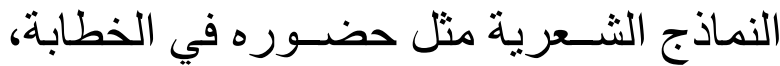

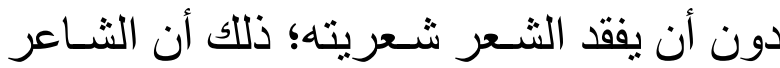

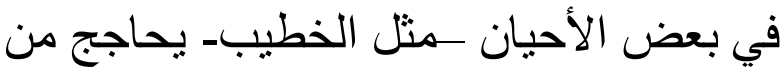

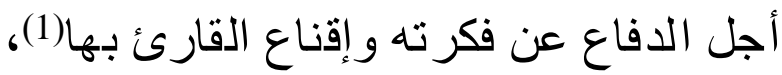

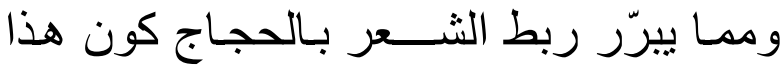

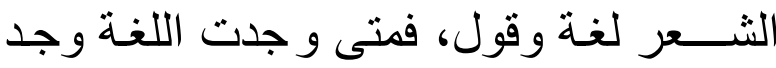

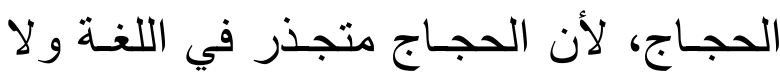


يمكن فصله عنها(2). و عليه، فإن الثـعر يسـنطيع القيام بالحجاج

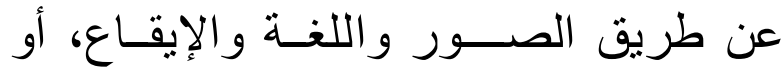

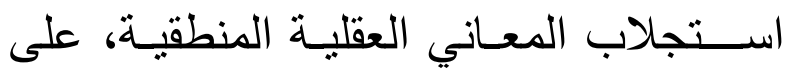

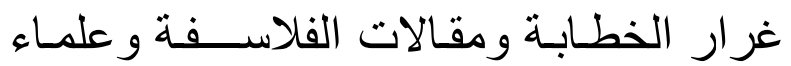
الكلام(3)، و هذا يعني أن أسـاليب الإقناع يمكن الفابل

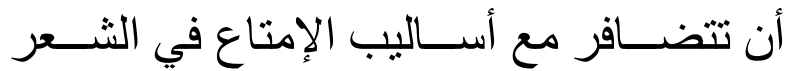
لتكونا أثرا فعالا في التأثير على المتلقي. وخلاصـــة القول إن الخطاب الثــــري

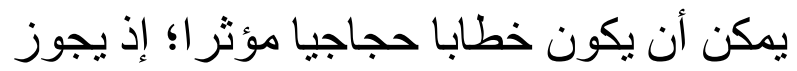

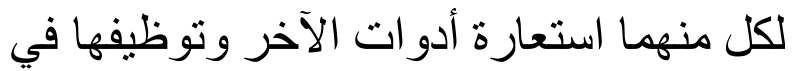

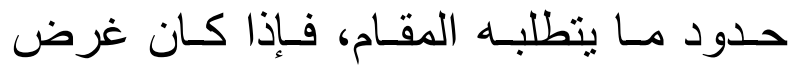

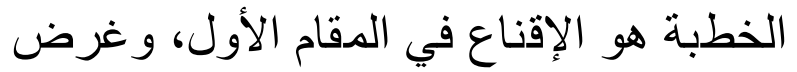
الثـــر هو الإثارة والإمتاع في المقام الأول، الثان.

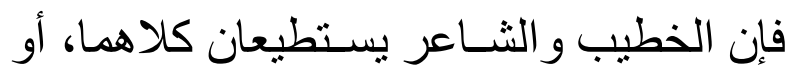
يجب عليهما - إن صــــح التعبير - اســـتعمال وســائل معينة لإقناع المخاطَبَ، لأنه المعني

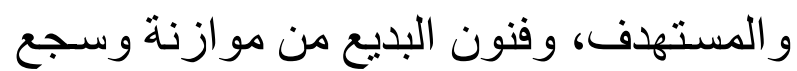

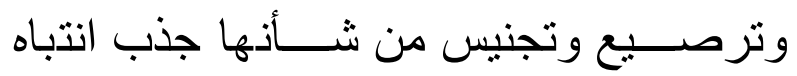

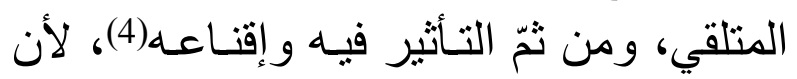
المحسنات البديعية ليست صور الفنية وتزينينية

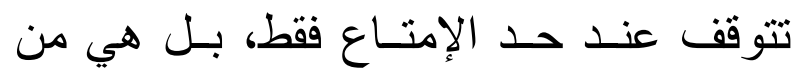
التقنيات الحجاجية، إذ لا يمكن فصـل الإعل الجمال عن الإقتـاع؛ لأن المعنى بحساجـة إلى جمـال
يزينها، كمـا أن المعنى الجميل تكون فعـاليتهـ على المتلقي أكبر (5)

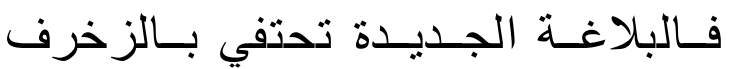

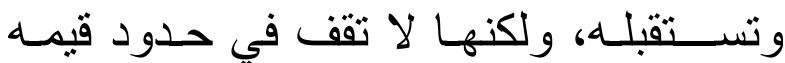
الجمالية فحسـب، بل تسـتغلها لكونهاو وسـيلة نـاجعـة للإبـداع من جهة، والإقناع من جهـة

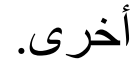

\section{ثانيا: استر اتيجيات الحجاج (الإقناع، البرهنة، الاستدلال)}

وثمة علاقة متينة بين هذه الاسـتر اتيجيات

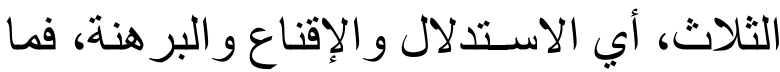

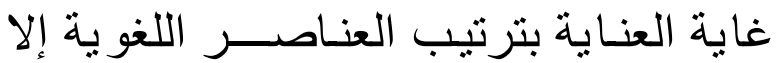

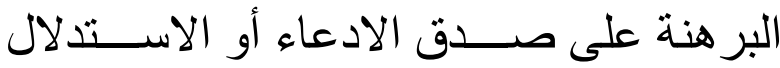
عليه، ليكون ذللك مسوّغا إلى إقناع المخاطَب.

$$
\text { أـ الإقناع: }
$$

يعدّ الإقناع أحد أهم اسـتر اتيجيات الحجاج

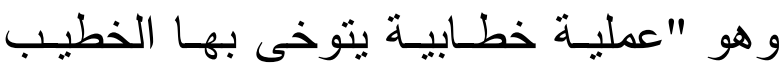

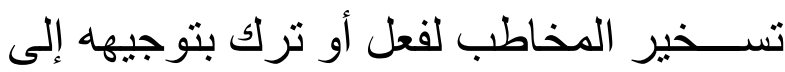

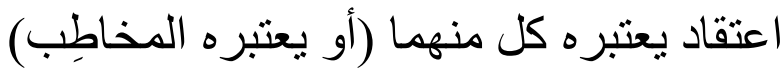

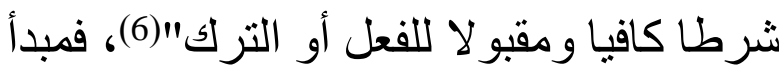
الإقناع هو الرغبة في الفعل أو الترك، ومنتهاه لتركاه

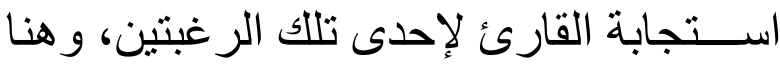

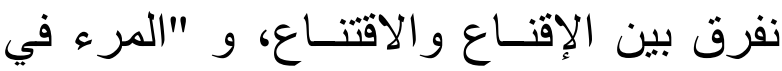

(5) ينظر: الدريدي، سامية: الحجاج في الشعر العربي: بنيته

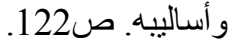
(6) ينظر : الثهري، عبد الهادي بن ظافر : استر اتيجيات الخطاب: مقاربة لغوية تداولية. بيروت: دار الكتاب الجديدة المتحدة، ط1،

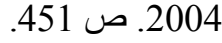




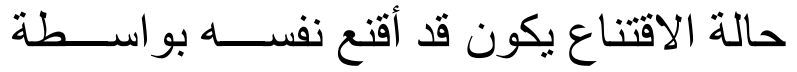

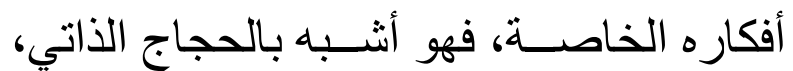

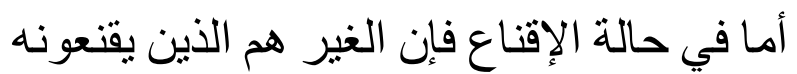

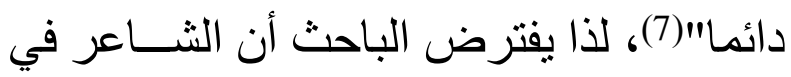

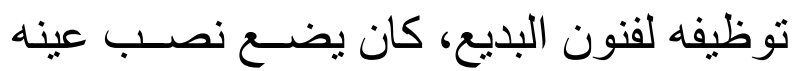

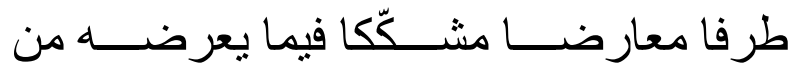
الأفكار و المعاني، لذا لجأ إلى هذه الأشـــــال

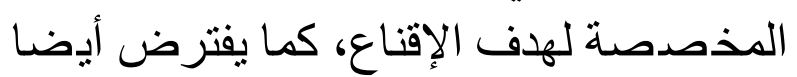

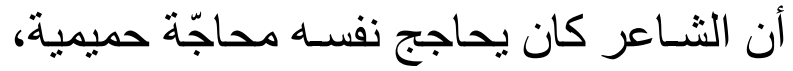
يهذف بها إلى الاقتناع.

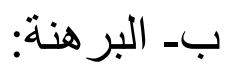

وهي اسـتنباط يسـعى إلى إثبات صــدقية

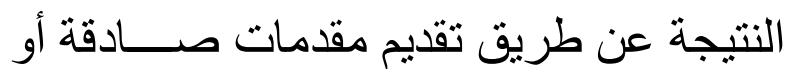
محتملة، معترف بها لدى المتحاورين (8).

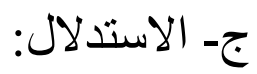

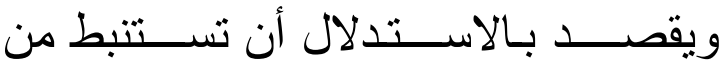

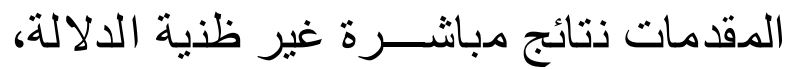

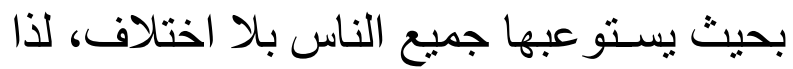

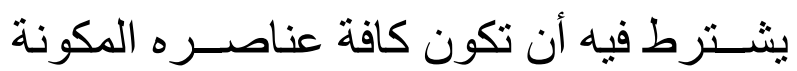

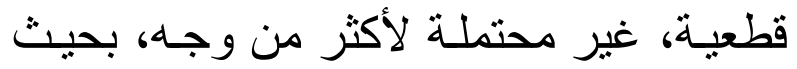

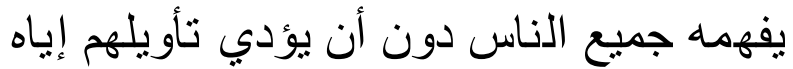
إلى اختلافات(9).

بناء على ما ســــق، فإن البحث ســـيتتبع

(7) صولة، عبد اللة: في نظرية الحجاج: دراسات وتطبيقات. تونس:

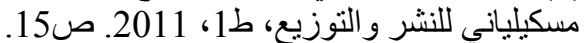

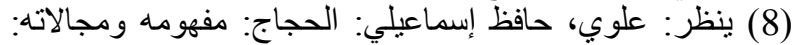

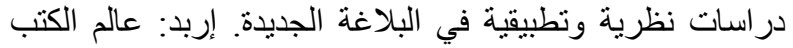

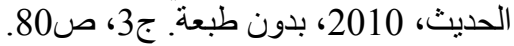

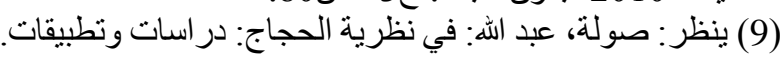

البـديع في نمـاذج من شـــر أبي الحســن البـن

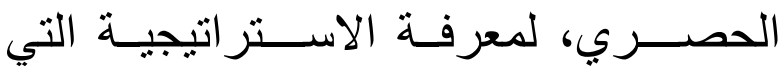

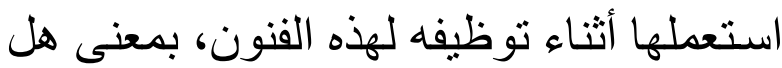

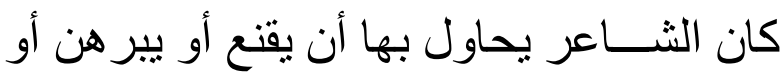

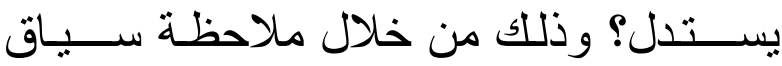

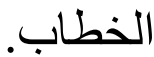

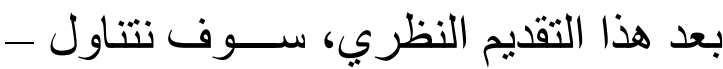

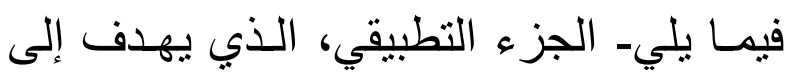

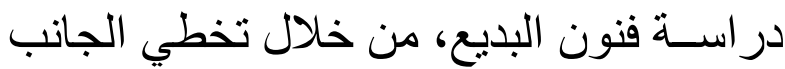

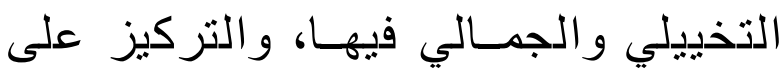

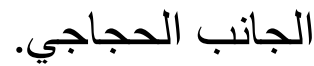
المبحث الأول: الحجاج التجريبي

يســـى هـــا النوع من الحجج حجــاجـا

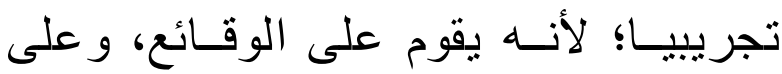

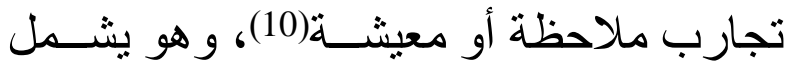

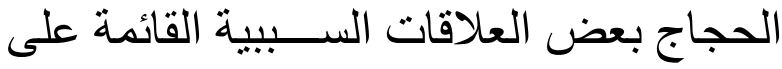
التبرير ، و الحجاج بو اسطة القر ائن، و الإيضساح

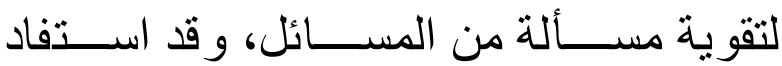
الحصــري من هـذه التقنيـات لأهميتهـا

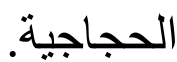

\section{المطلب الأول: التبرير أو العلاقات السببية:}

وغاية هذا الضــرب من الحجاج، هو بيان وجود علاقة سـبيية بين حدثين (11)، و غالبا ما لـان

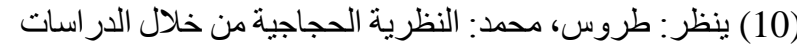

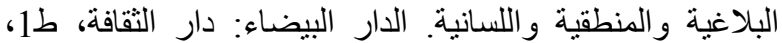

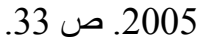

(11) ينظر: بلانتان، كريستيان: الحجاج. ترجمة: عبد القادر

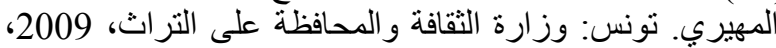

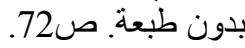


يكون هذا السـبـب مخالفا للسـبـب الحقيقي(12)،

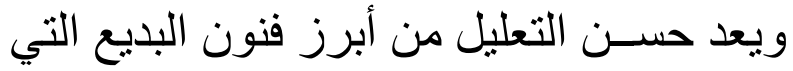

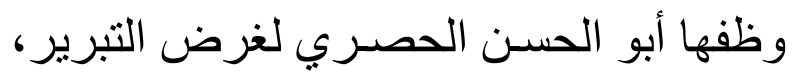

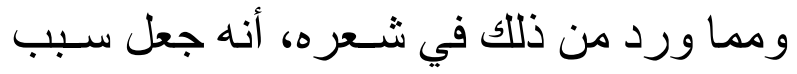

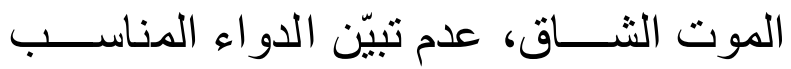

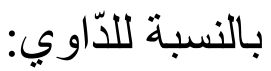

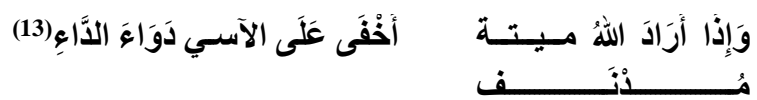

هنا يربط الثــاعر شــدة وصـعوبة الموت

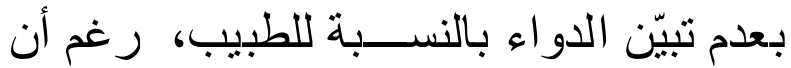

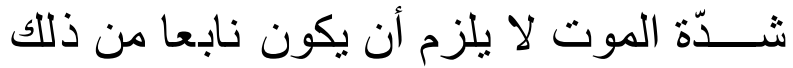

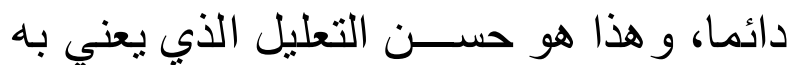

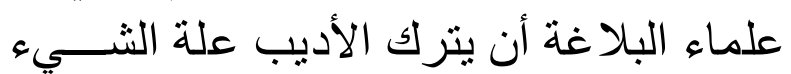
الحقيقية، ويستبدلها بعلة أدبية طريفة، وتكون الاديب

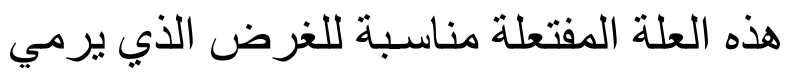

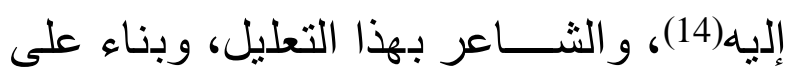

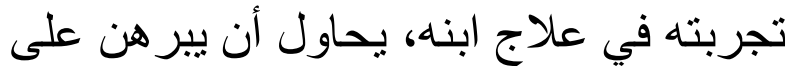
حجم المجهودات التي بذلها في علاج ابنه، إلا بلا بله أنّ الله لم يوّفقه في سعيه. فحسن التعليل _هنا- يضطلع بوظيفة مهمة من وظائف الصـورة الثـعرية، وهي تصـوير تجربة الثـــاعر، و إيصــــال هذه التجربة إلى وهي الآخرين(15) - (15)

(12) ينظر : طروس، محمد: النظرية الحجاجية من خلال الدراسات

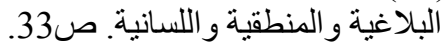

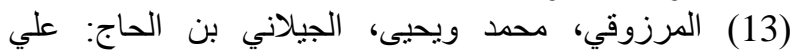

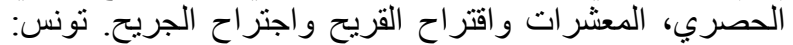

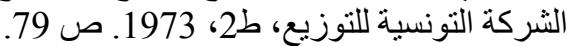
(14) بنظر: السبكي، أُحمد بن علي: عرئئ عروس الأفراح في شرح

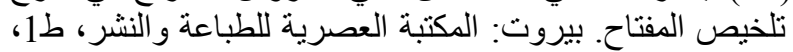
266/2.2003-1423

\section{المطلب الثاني: حجة القرينة:}

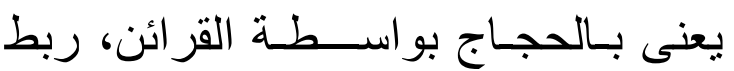

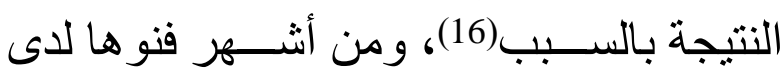
الحصــري، الجناس، ومما ورد من ذللك قوله لهاءله

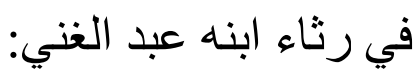

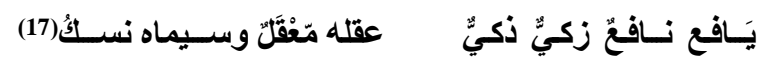

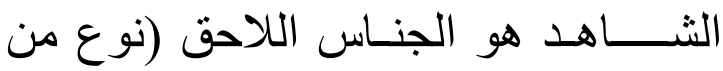

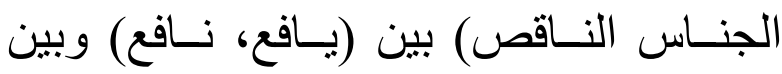

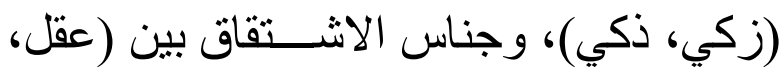

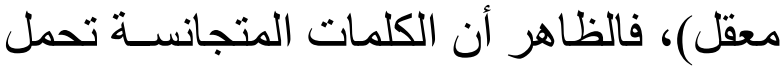

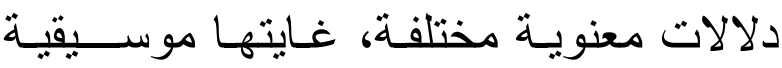

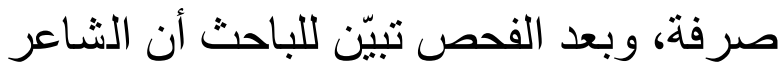

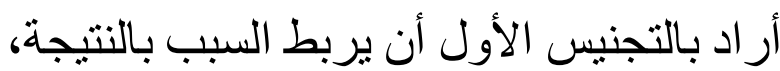

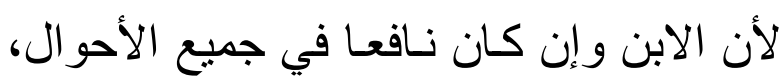

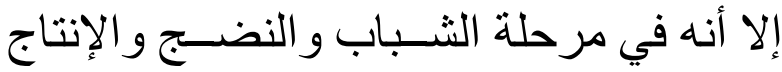
يكتمل نفعه، و هذا هو المعنى المر اد تثــــــيله بقوله: (بافع نافع) فالنفع، إنما سببه اليفع. أمسا التجنيس التـاني:(زكي، ذكي)، فهو

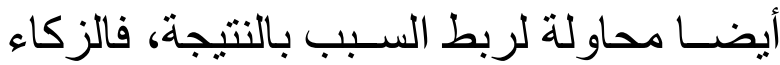

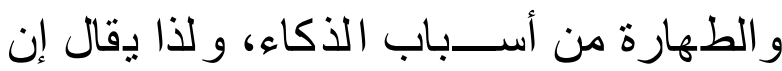
الاستحمام يجدد النشاط للجسم و العقل. وهكذا الحسال مع التجنيس التـالـث بين:

(15) ينظر: داحم أسية: الإيقاع المعنوي في الصورة الثعرية.

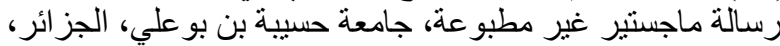

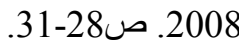
(16) ينظر: بلانتان، كريستيان: الحجاج. ترجمة: عبد القادر

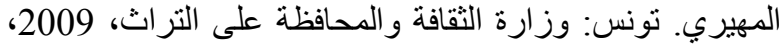

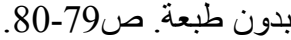
(17) المرزوقي، محمد ويحيى، الجيلاني بن الحاج: علي الجئي الحصري، المعشرات و اقتراح القريح واجتراح الجريح. ص لـ 148. 
(العقل و المعقل)، فكون هذا الابن ذا تفكير

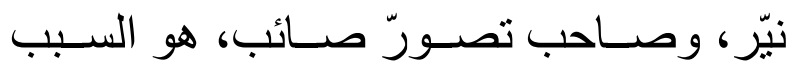
الذي دفع بالناس إلى اللجوء إليه، وجعلهم إياه هو معقلا.

ونلاحظ في صــدارة البيت حذف المســن

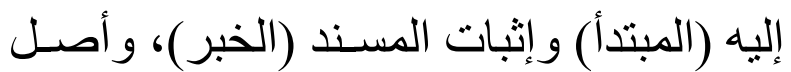

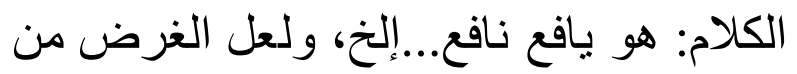
هذا الحذف هو التعظيم و التفخيم. لافع ونافي

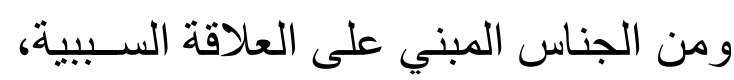

ربط الثناعر الحصري بين الغنى و الغواني:

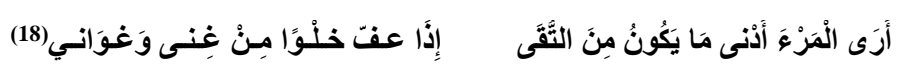

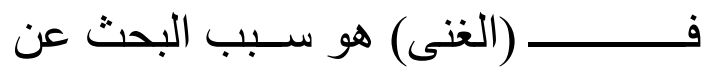

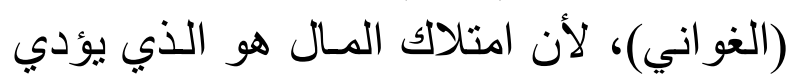

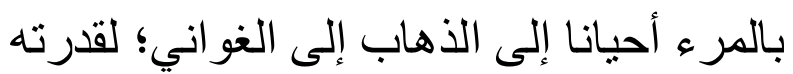

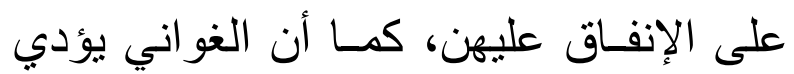

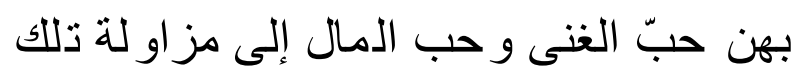

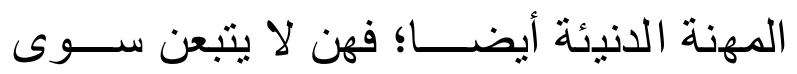

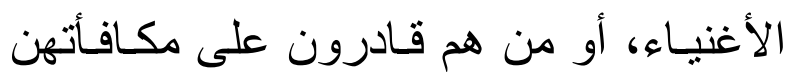
مقابل رقصهن أو بيعهن لعروضهن.

المطلب الثالث: حجة الإيضاح أو حجة

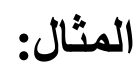

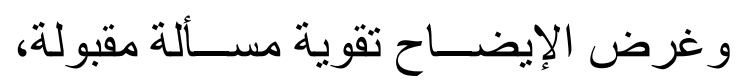

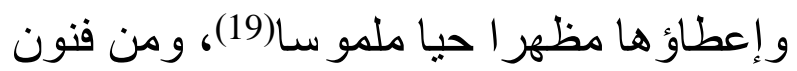
البديع التي قامت بحجة الإيضاح في شعر أبي

(18) (18) المصدر السابق. ص173. (19) ينظر : طروس، محمد: النظرية الحجاجية من خلال الدر اسات البلاغية والمنطقية و اللسانية. ص35. صنية.

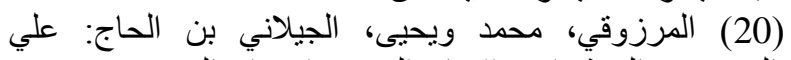

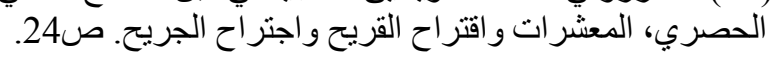

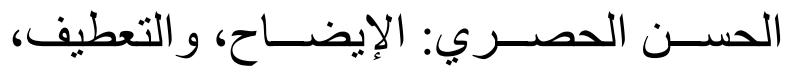
و الترديد، و التفريق. يقول شاعرنا:

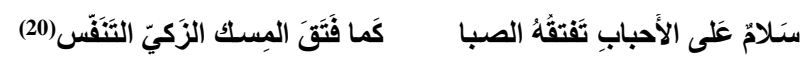
الثــــاهد هو التعطيف في قولـه: (تفتقهـ،

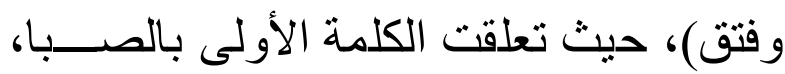
وتعلقت الثانية بالمسك، ويقصد بالتعطيف "أن بأن

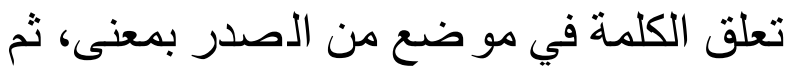

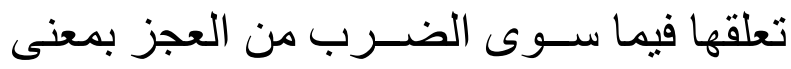

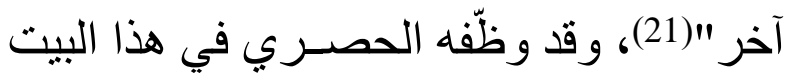

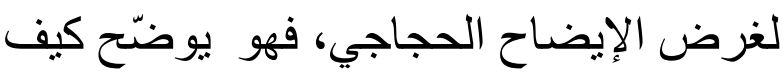
يريد أن يصـل ســلامه إلى أحبابه، فتخيّل أن فئل

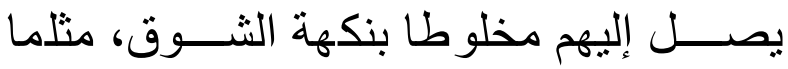
يستمتع المرء بتتفس المسك الزكي، و الشاعر

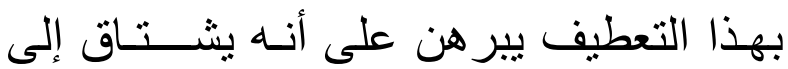
أحبابه، شوقا طيبا نقبا.

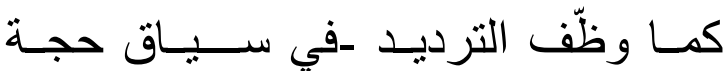
الإيضاح أيضا- وذللك في قوله:

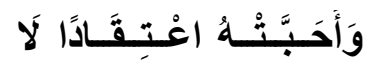
(22)

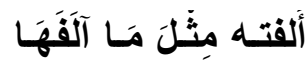
يتمثنل الترديـد في تكرار كلمتي: (ألفتهـه،

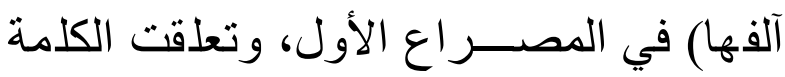

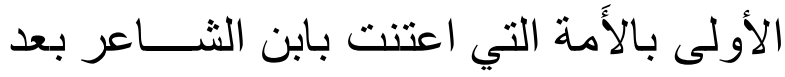

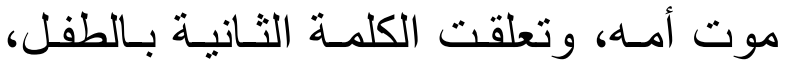
و الترديد عند ابن رشيق وتطفيق القيرواني: " أن يأتي 
الثــاعر بلفظة متعلقة بمعنى، ثم يردها بعينها

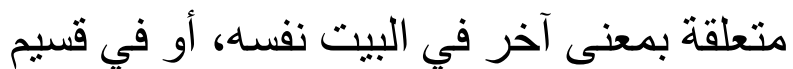

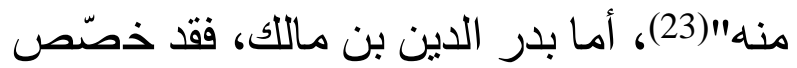

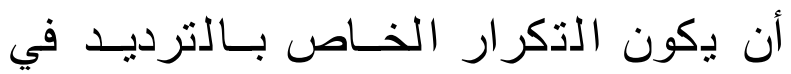

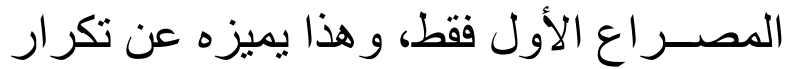

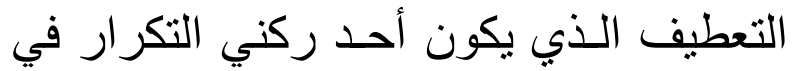

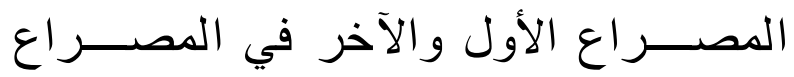

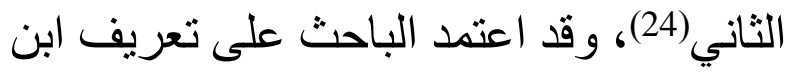

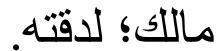

وقد وظّفه الحصـــري هنا ليوضّـــح طبيعة الحب بين تلك الحب و هذا الطفل، وهو الحب المتبادل، وهذا وقد مكّن هذا الإيضـاح الثناعر

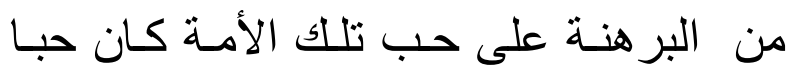

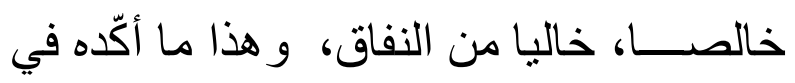

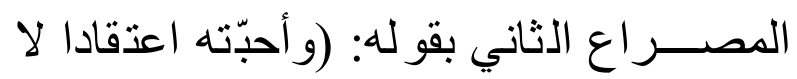
ملق).

ويستمر الثناعر في تعزيز حجة الإيضاح،

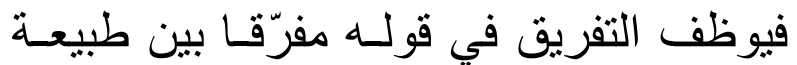

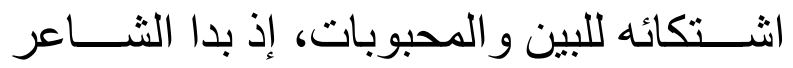
متأثر ا بالبين، على خلافهنّ، يقول:

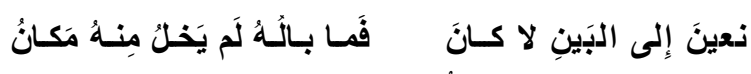

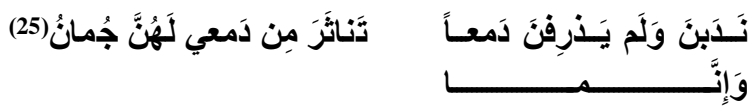
(23) ابن رشيق، الحسن: العدة في محاسن الثعر وآدابه. بيروت:

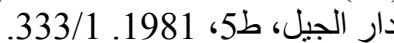
(24) ينظر: ابن مالك، بدر الدين: المصباح في المعاني والبيان

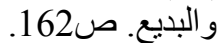
(25) المرزوقي، محمد ويحيى، الجيلاني بن الحاج: علي الحصري، المعرات و اقتراح القريح واجتراح الجريح. ص اع 37.
الثـــــاهد هو البيت الثناني، حيـث يفرّق

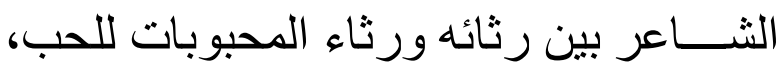

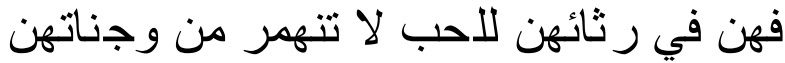

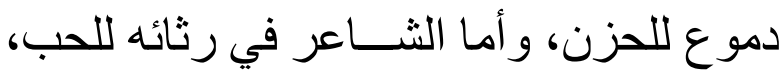
تنثر عيونه دمو عا ولؤلؤا.

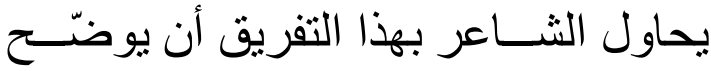

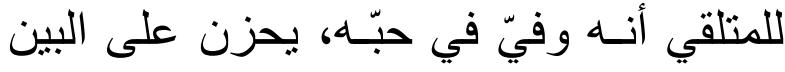
و الفراق، و حديثه هنا عن المحبو بات يحتمل

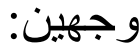

أحدهما أن يكون الثــاعر قد أحب نســاء

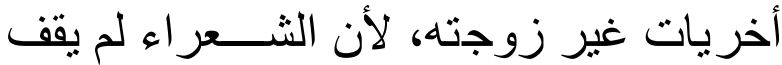

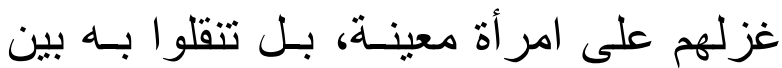
الفتيات تنقل الفر اش بين الأز ها (26)، و الآخر أن هذا الحديث يوحي بعثـق الثــاعر للجمال

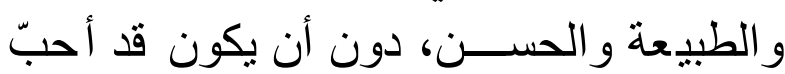

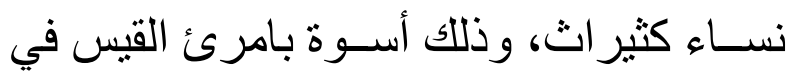

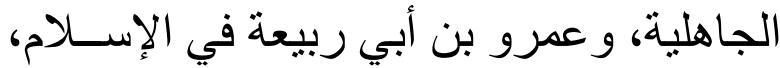

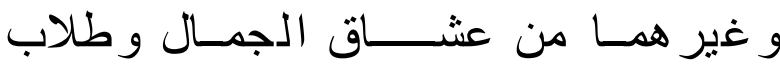
اللذائذ(27).

و الوجه التاني أقرب إلى اعتقاد الباحث،

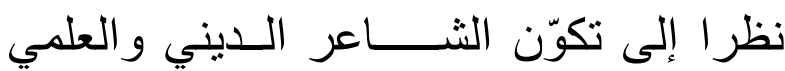

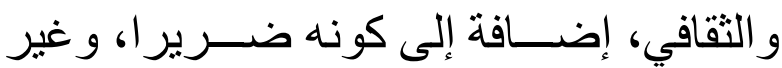

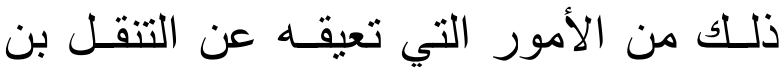

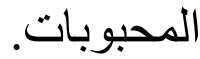




\section{المبحث الثاني: الحجاج القلسفي}

ومن فرو عه المتصلة بألو ان البديع في هذا

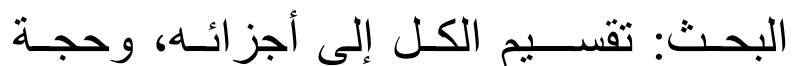

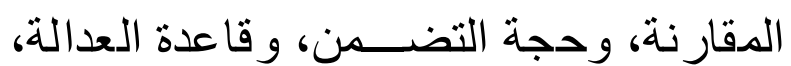
وقاعدة السـابق، وحجة المتلازمين، وتحصيل الحاصل أو الحجاج بالحشو.

يعّد البلاغيون هذا النوع من الحجج حججا

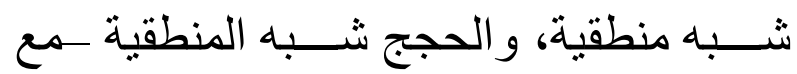

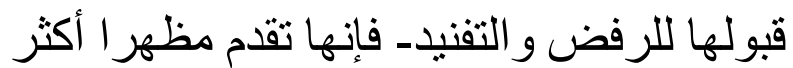

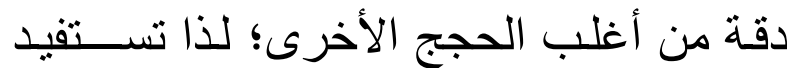

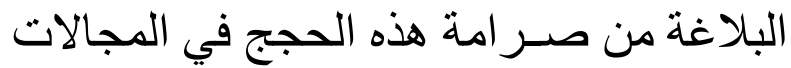
الخلافية(28)، ومن فرو عها:

\section{المطلب الأول: تقسيم الكل إلى أجزائه:}

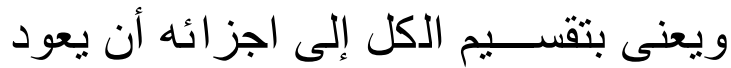

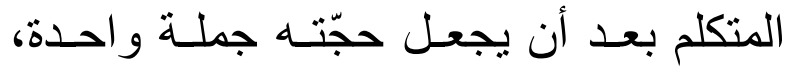
ليفنّد ها ويعدّد أجز اءها ها إن كانت ذات أجز اء، وذللك للحفاظ على قوّتها الحجاجية، و البرهنة على وجود أجز اء الثيء موضوع التقئيم(29). ومن الفنون البديعية التي وظّفها الثــــاعر

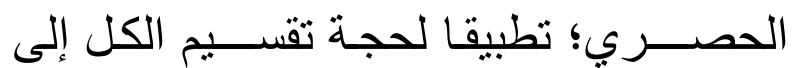

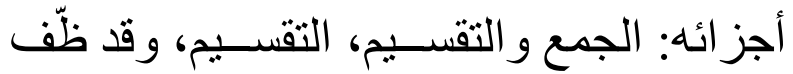

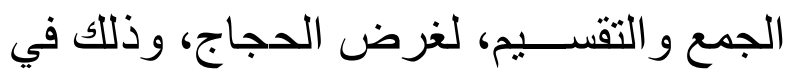

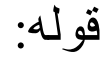

(28) ينظر : طروس، محمد: النظرية الحجاجية من خلال الدر اسات

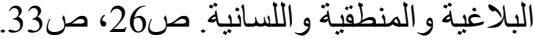
(29) ينظر: صولة، عبد الله: في نظرية الحجاج: دراسات وتطبيقات. ص48)

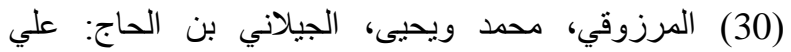
الحصري، المعشّرات و اقتر اح القريح واجترأح الجريح. ص 29.

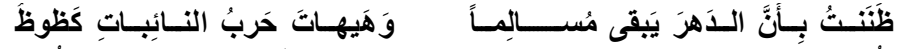

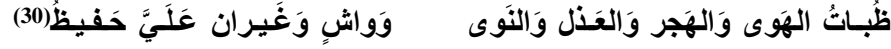

يبـدو الجمع في قولـه: (حرب النـائبـات

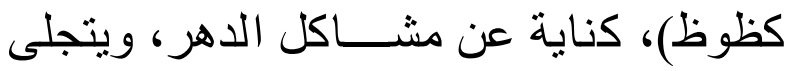
التقسـيم في تعداد تللك المشــاكل، و التي تمثلت

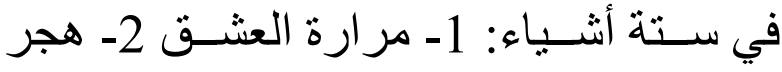

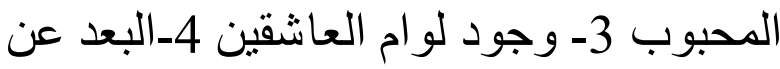

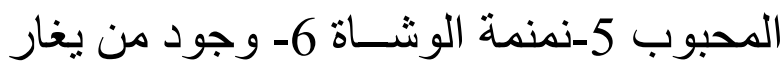

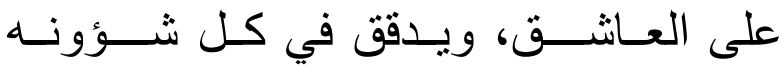
وتصـرفاته، يريد الثـاعر بذكر هذه الأجز اء،

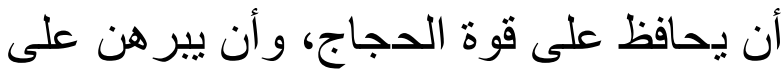

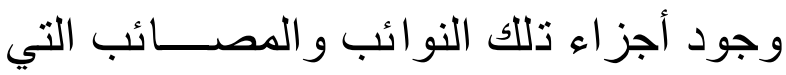
نســـها إلى الدهر ، و إظهار ها للمتلقي ليكون

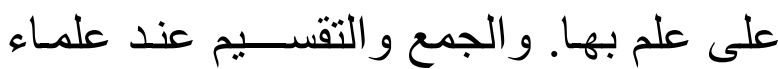
البلا غة " أن تجمع أمور ا كثيرة تحت ولفي حكم ثم تقسم أو تقسم ثم تجمع" (31).

\section{المطلب الثاني: فنون حجة المقارنة:} و المقارنة اســتر اتيحية حجاجية، و لا يلزم أن تكون حقبقة أو و اقعية، لأنها تنأتى أحيانا

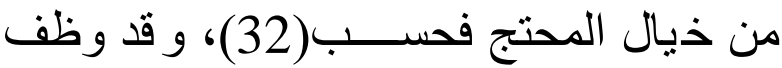

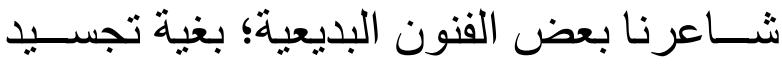

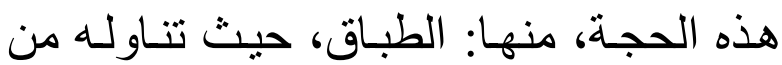

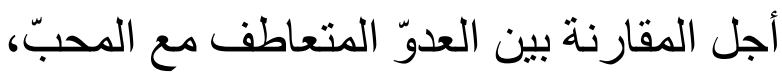

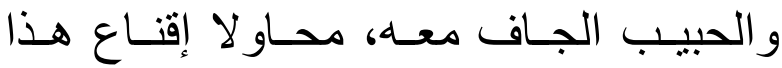


الحبيب بتغيير سلوكه، وذلك في قوله:

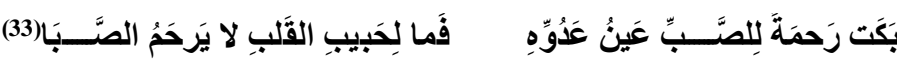

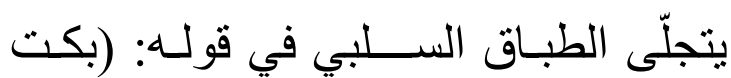

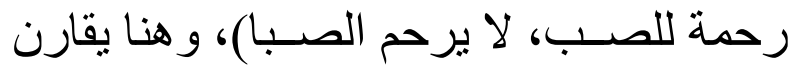

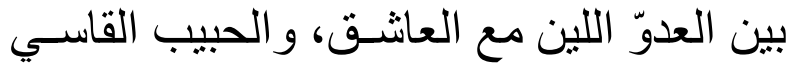

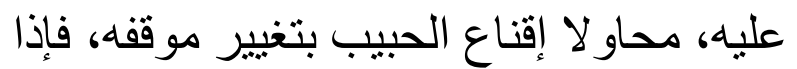
كان الأعداء يشاطرون العاثثق شعور الهاء المرير

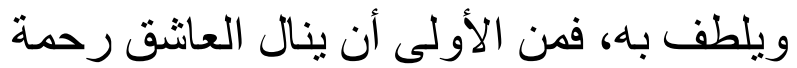
حبيبه، و الغرض من هذه المقارنة، هو تحريك التك

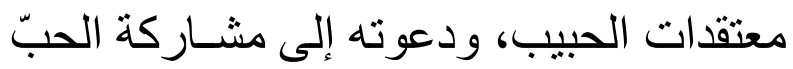

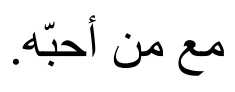

\section{المطلب الثالث: فنون حجة التضمن:}

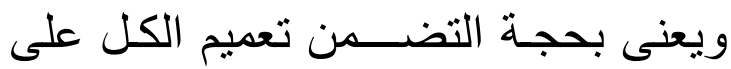

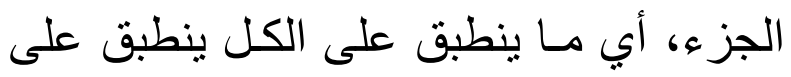

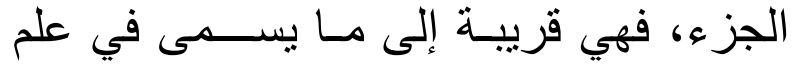

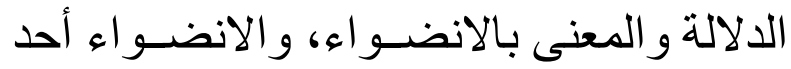

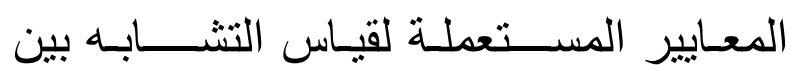

$$
\text { المعاني(34). }
$$

وقد اســتعمل الثــــاعر رد العجز على في

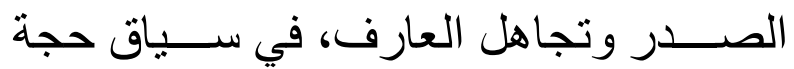
التضـــــن، للتســــاوي بين الناس في إمكانية

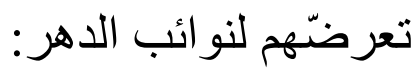

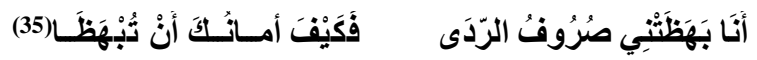

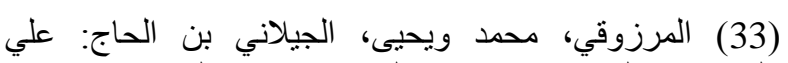

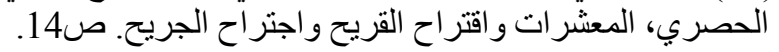

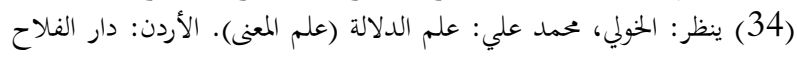

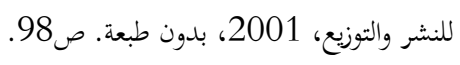

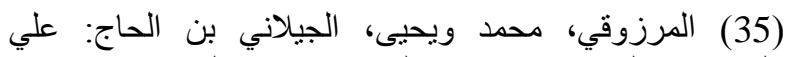
الحصري، المعشر اتو واقتر اح القريح واجتراح الجريح. ص 143.
يتمثنل رد العجز على الصـدر في التكرار، إنه

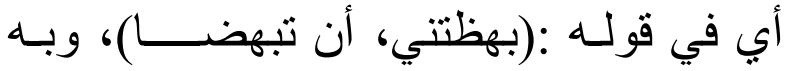
يحاول الشاعر الاستدلال على أن ما أورثه له له

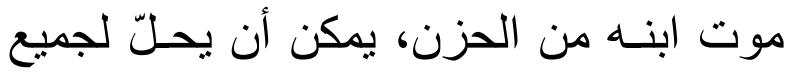

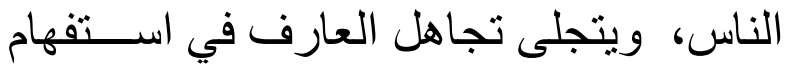

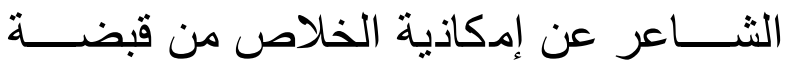

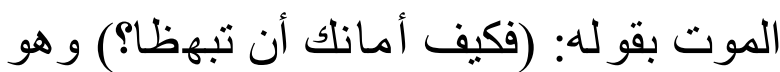
يعلم أنه لا مفر من الموت، كل ذلان للك للتأكيد على أنه لا نجاة من الموت. لات من الموت كل

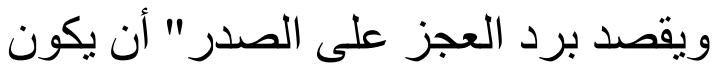

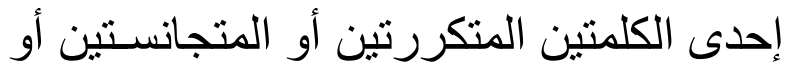

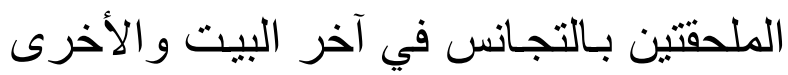

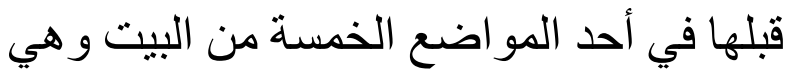

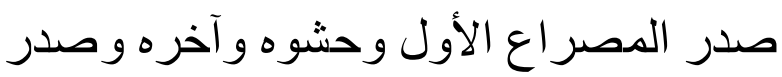

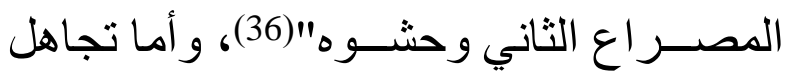

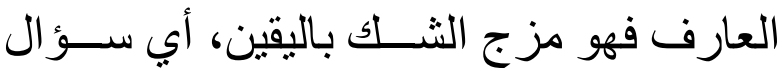
المتكلم عن شيء يعرفه تجاهلا منه(37).

\section{المطلب الرابع: فنون قاعدة العدالة:}

ولا تختلف قـاعـدة العـدالـة عن حجـة التضــــ؛ إذ تفترض أن الحالات المدروســة العـة

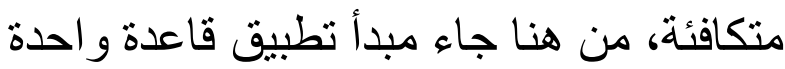

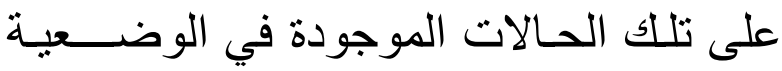
نفســـها(38) ، ومن الفنون البديعية التي يمكن

(36) السكاكي، يوسف بن أبي بكر : مفتاح العلوم. ص430.

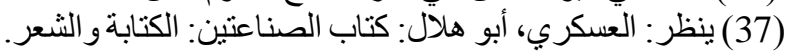

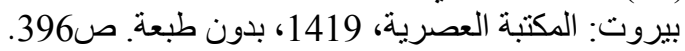
(38) ينظر: صولة، عبد الله: في نظرية الحجاج: دراسات

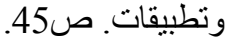


در اســتها ضـــمن قاعدة العدالة: الموازنة و السجع.

و قد وظّّف الموازنة لتعزيز حجة العدالة

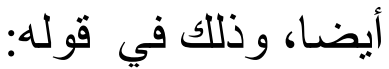

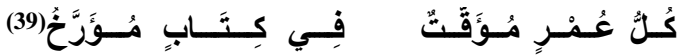

تبـدو الموازنــة في كلمتي: (مؤقتـ، مؤرخ)، و الموازنة هي" تسـاوي الفاصـلتين، أي: الكلمتين الأخيرتين من الفقرتين أو من

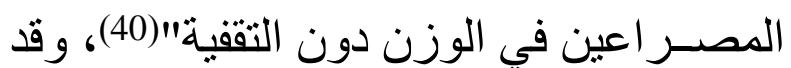
استعملها الحصري في هذا البيت للاستدلال البـال

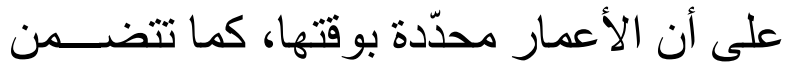

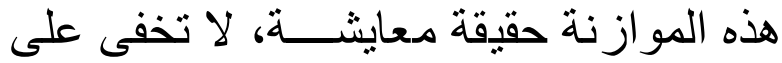

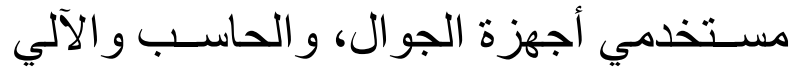
وغيرهمـا، وهي كون الوقـت والتــاريخ متلازمين.

كما تناول السجع في قوله:

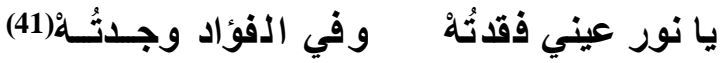

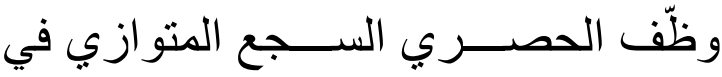
قوله: (فقدته، وجدته)، و السجع المتوازي، هو الهوا

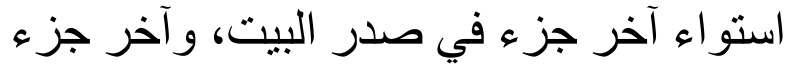

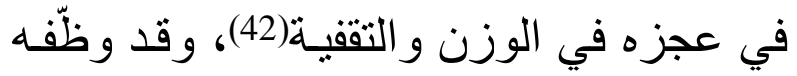
الثـاعر هنا لتجسيد قاعدة العدالة، فهو يعادل

بين حالتين متتافرتين، موت ابنه، وحضــوره

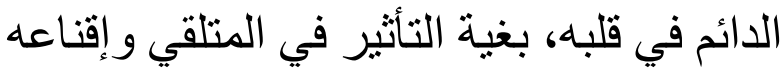
بأن ما يكنّه لابنه من الحبّ، يجعله غير قابه فئه على التمييز بين وجوده معاه، و غيابه عنه. المطلب الخامس: فنون قاعدة السابق: تفترض هذه القاعدة تمـانتلا بين حسالتين

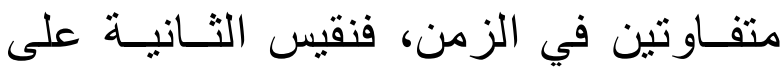

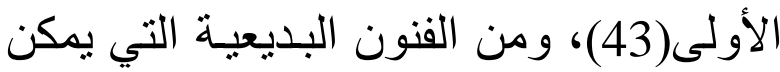
أن تضـطلع بتطبيق هذه القاعدة: الجناس، وقد تناوله الحصري في قوله:

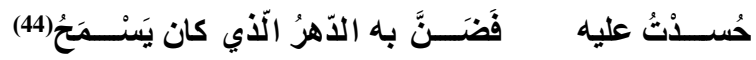

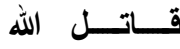
حساستــــ

استعمل الشاعر جناس الاشتقاق في قوله:

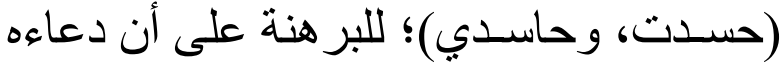

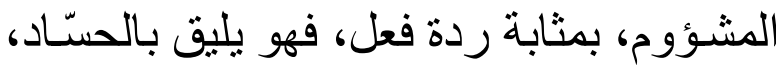

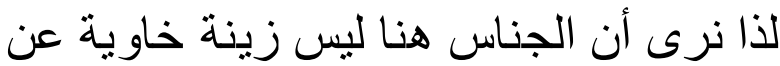

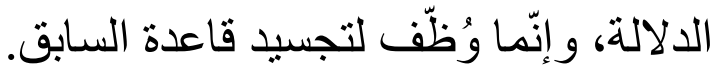
المطلب السادس: حجة المتلازمين: ويسمي بعض الدارسين حجة المتلازمين،

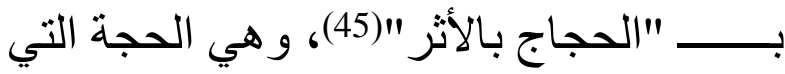

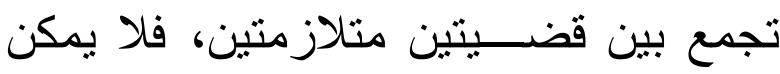
اعتبار أحدهما دون اسـتـحضـــار الآخر مثل:

(39) المرزوفي، محمد ويحيى، الجيلاني بن الحاج: علي الجيجئ

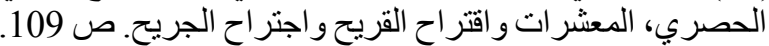

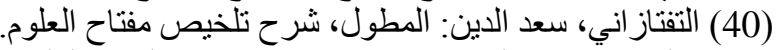
تحقيق الدكتور: عبد الحميد هنداوي. بيروت: دالئ دار الكتب العلمية.

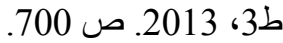

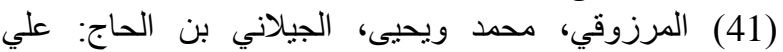
الحصري، المعشر ات و اقتر اح القريح و اجتراح الجريح. ص 89.
(42) ينظر : التفتاز اني، سعد الدين: المطول، شرح تلخيص مفتاح

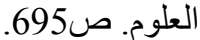
(43) ينظر : طروس، محمد: النظرية الحجاجية من خلال الدراسات البلاغية و المنطقية و اللسانية. ص323.

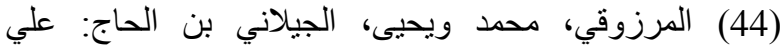

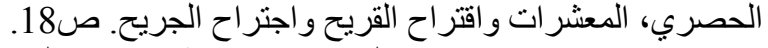

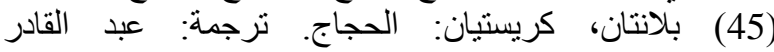

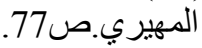


(لا نار بدون دخان)(46)، وهي قريبة إلى فن

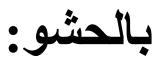
التعليق في علم البديع، و الذي يعني أن بـأني ولني المتكلم بمعنى، ثم يعلق به معنى آخر (47).

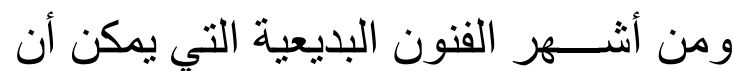
تدرس ضمن حجة المتلازمين: التذييل، وظظّفه الحصري في شعره، تطبيقا لحجة المتلازمين،

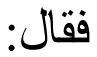

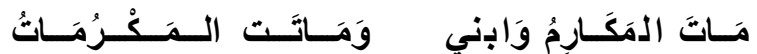

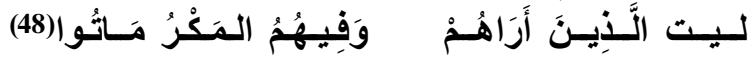

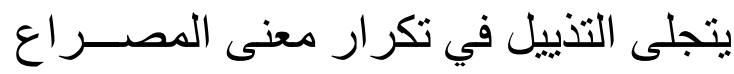

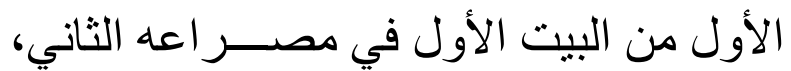

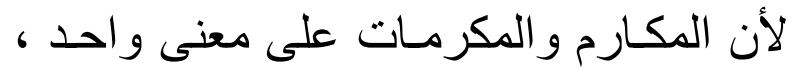

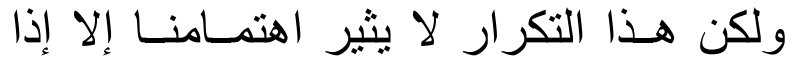

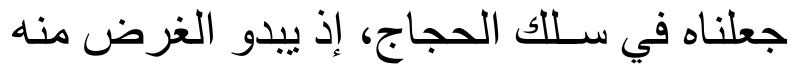

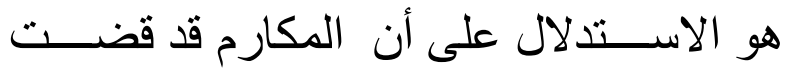
نحبها، بسـبـ موت صــاحبها، الذي هو عبد الإن

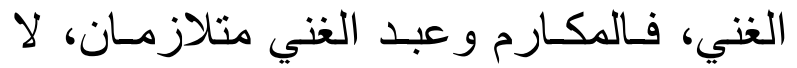
يتبخّر أحدهما ويبقى الآخر. والتذييـل هو الإتيـان -بعد إتمـام الكلام-

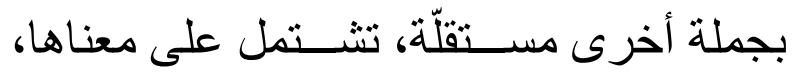
تأكيداً لمنطوق الكلام، أو لمفهومه(49). المطلب السابع: تحصيل الحاصل أو الحجاج

(46) ينظر : طروس، محمد: النظرية الحجاجية من خلال الدراسات البلاغية و المنطقية و اللسانية. ص32. (47) ينظر : ابن منقة، أسامة: البديع في نقد الثُعر . تحقيق الدكتور:

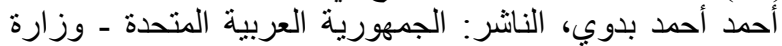
الثقافة و الإرشاد القومي ـ الإقليم الجنوبي ـ الإدارة العامة للثقافة،

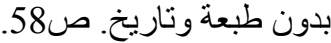

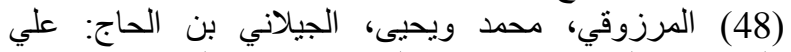
الحصري، المعشرات و اقتر اح القريح و اجتراح الجريح. ص بل 92.
(49) ينظر: الطالبي، يحيى بن حمزة: الطراز لأسرار البلاغة الإنة وعلوم حقائق الإعجاز. بيروت: المكتبة العصرية، ط1، لإن 1423.

(50) ينظر: الخطيب، محمد عبد الفتاح: المعنى وتثكله في الدرس

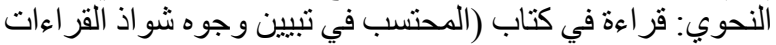

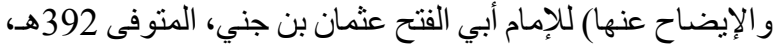

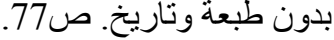
(51) ينظر: علوي، حافظ إسماعيلي: الحجاج: مفهومه ومجالاته:

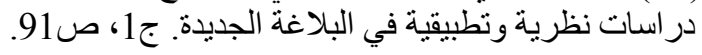




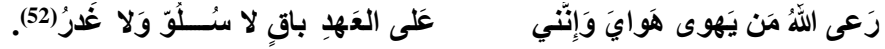

يتجلّى تكر ار المعنى دون اللفظ في قو له:

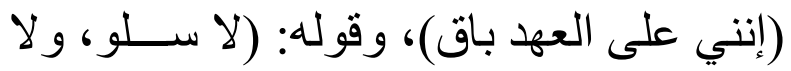

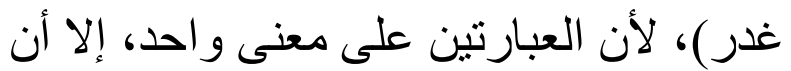

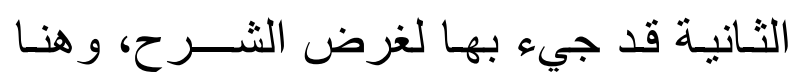
يحاول الثـــاعر إقناع المتلقي/ المحبوبة بأنها

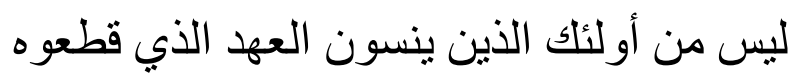

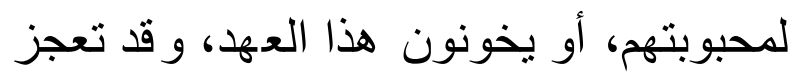

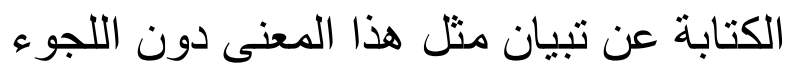

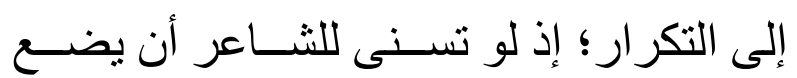

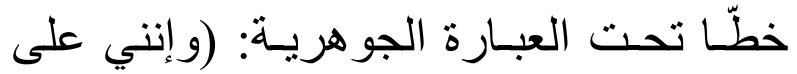

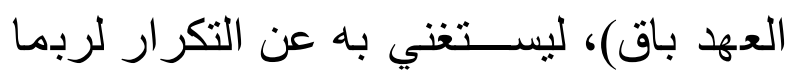

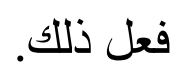

كما اسـتعمل الإرصـاد في سـياق الحجاج،

$$
\text { وذلك في قوله: }
$$

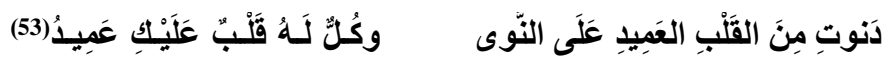

يتمثل الإرصساد في كلمة: (العمبد) الواردة

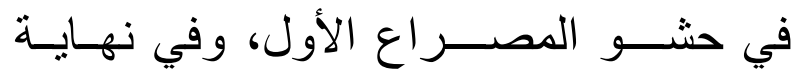

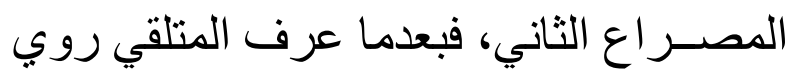

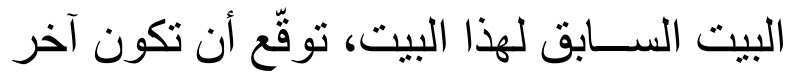

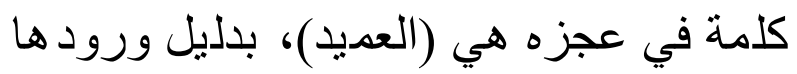

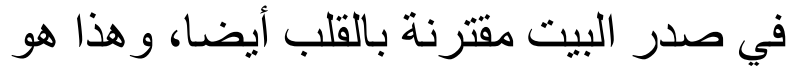

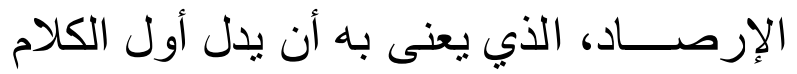

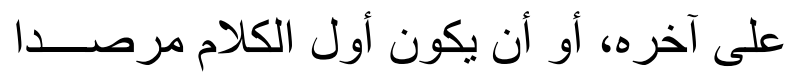

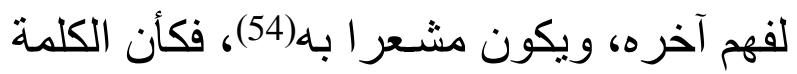

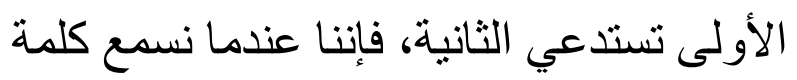

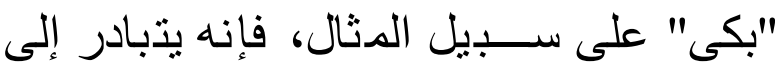
أذهاننا كلمات، مثل: الطفل، الحزن، الدموع.

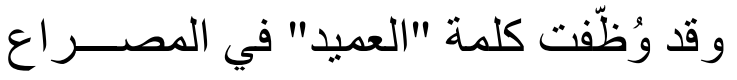

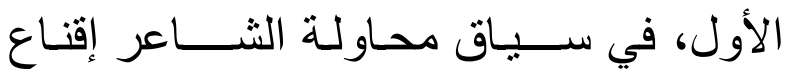

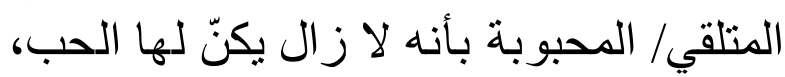

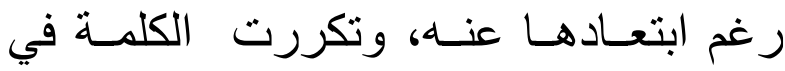

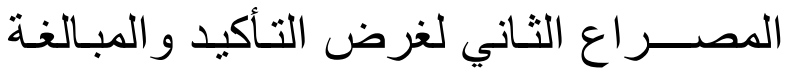

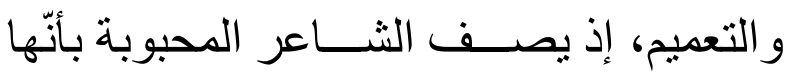

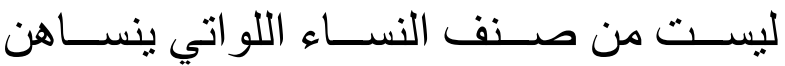
القلوب، و أن قيمتها معروفة لدى جميع الناس: (وكل قلب عليكِ عميد).

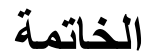

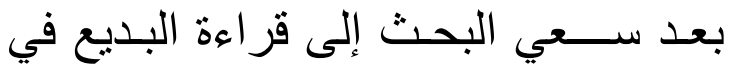

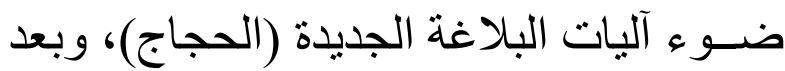

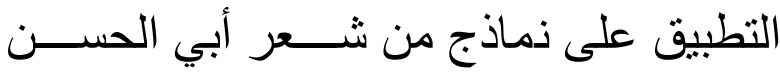
الحصري القيرواني، أسفر عن النتائج التالية: 1- إذا كانت البلاغة الجديدة تهتم بالزخرف،

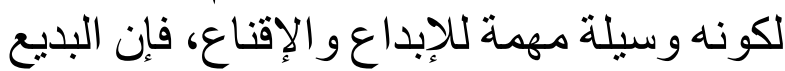

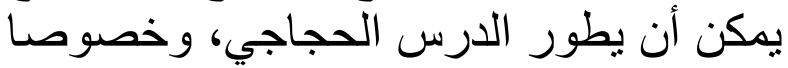

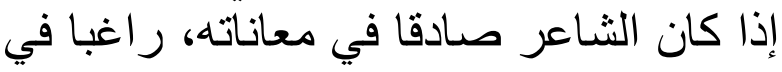

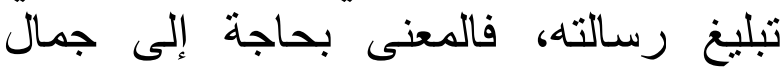

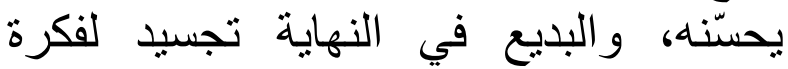
الحجاج ودلالة على وجود فها، وقد تبيّن للباحث

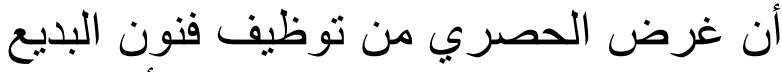
هو محاولة جذب انتباه المتلقي، و التأثثير فيه، التئ، وتتوعت استر اتيجيته في ذللك، إذ كان يقصد والتيل

(54) الطالبي، يحيى بن حمزة: الطراز لأسرار البلاغة وعلوم حقائق الإعجاز. 168/2. 
ببعض الفنون إقناع المنلقي، مثل: (الطباق،

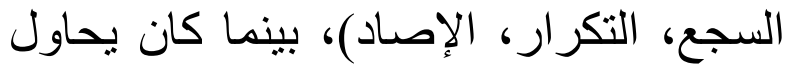

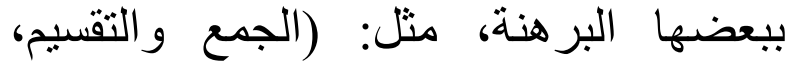

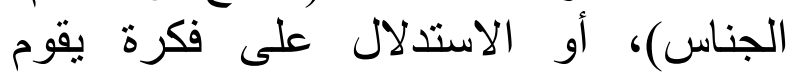

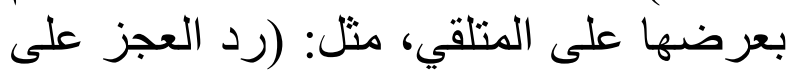

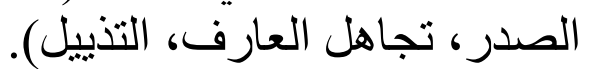

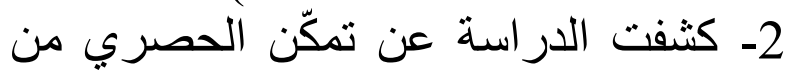

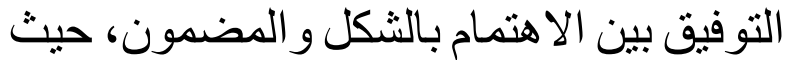

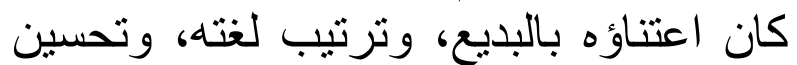

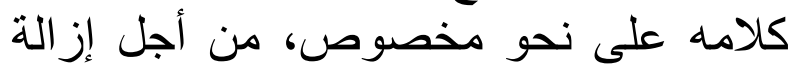
الغبار عن الكلام، و إعطائه حقه من التوضيح التوليح الزيح

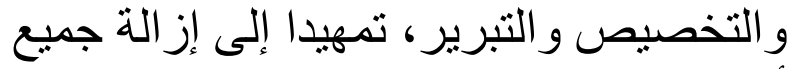
ألوان الثكوك من نفس المتلقي. 3- لم يكن تكرار الثناعر لعناصر متفقة أو دلفي

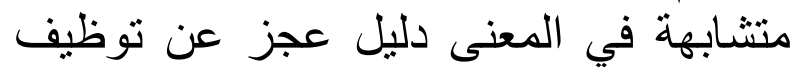

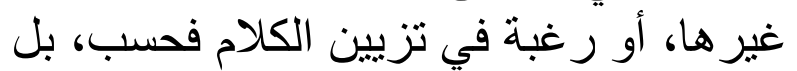
لأنه كان ملزما بهذا التكر ار لأهميته التأثيرية.

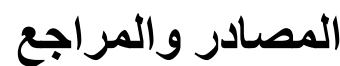

إبراهيم، البخاري عبد المحمود الثيخ.

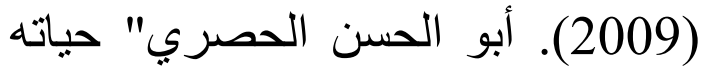
وشعره". رسالة ماجستير غير مطبو عة، الو الهري جامعة أم درمان، السودان.

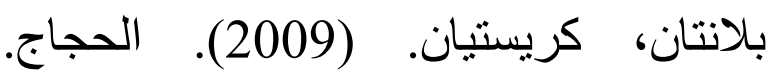
ترجمة: عبد القادر المريري. تونس: وزارة الثقافة و المحافظة على التراثل

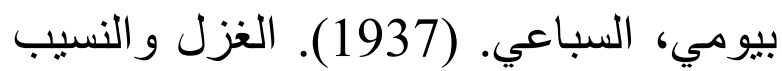
في شعر حافظ .صحيفة دار العلوم

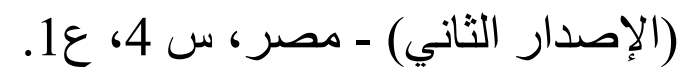

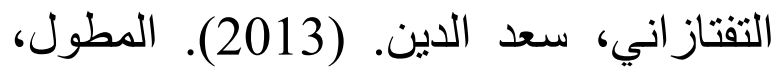

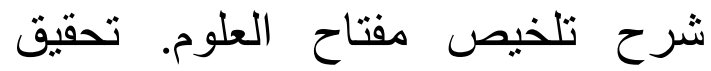

الدكتور: عبد الحميد هنداوي. بيروت:

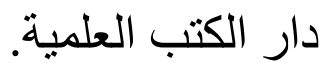
ابن جعفر، قدامة. (1400هـ-1980م). نقد النثر أو كتاب البيان. بيروت: دار الكتب العليمة.

الخطيب، محمد عبد الفتاح. (؟).) المعنى وتتكله في الدرس النحوي: قراعة في في كتاب (المحتسب في تبيين وجوه شواء التوري القراءات والإيضاح عنها) للإمام أبي الفتح عثمان بن جني، المنوفى 392هـ. الخولي، محمد علي. (2001). علم الدلالة (علم المعنى). الأردن: دار الفلاح للنشر

$$
\text { و التوزيع. }
$$

داحم أسية. (2008). الإيقاع المعنوي في الصورة الشعرية. رسالة ماجستير غير الإعلة فئري

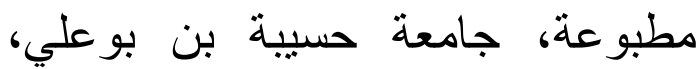

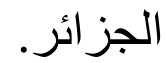

الدريدي، سامية. (2011). الحجاج في الثعر الثر الثرب العربي: بنيته و أساليبه. إربد- الأردن: عالم الكتب الحديث. ابن شيق، الحسن. (1981). العددة في

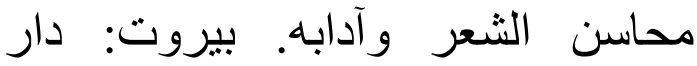
السبكي، أحمد بن علي. (1423 هـ-2003). عروس الأفراح في شرح الئ تلنيص

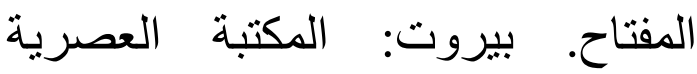
للطباعة و النشر. 
السكاكي، يوسف بن أبي بكر. (1407هـ -

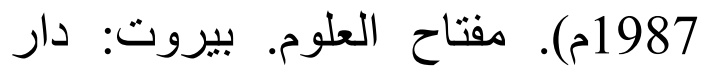

$$
\text { الكتب العلمية. }
$$

الثهري، عبد الهادي بن ظافر. (2004). استراتيجيات الخطاب: مقاربة لغوية التية تداولية. بيروت: دار الكتاب الجديدة

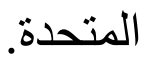

صادق، مثنى كاظم. (2015). أسلوبية الحجاج التداولي و والبلاغي: تنظير وتطبيق على السور المكية. تونس: كلمة للنشر و التوزيع. صولة، عبد الله. (2011). في نظرية الحجاج: دراسات وتطبيقات. تونس: مسكيلياني للنشر و التوزيع.

الطالبي، يحيى بن حمزة. (1423). الطراز لأسرار البلاغة ولئ علوم حقائق الإعجاز.

$$
\text { بيروت: المكتبة العصرية. }
$$

طروس، محمد. (2005). النظرية الحجاجية من خلال الدراسات البلاغية والمنطقية و اللسانية. الدار البيضاء: دار الثقافة.

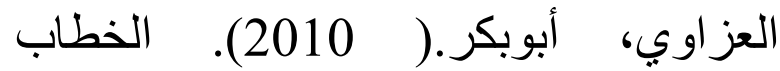
والحجاج. بيروت: مؤسسة الرحاب

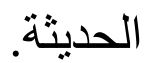

العسكري، أبو هلال. (1419). كتاب الصناعتين: الكتابة و الثعر. بيروت: المكتبة العصرية. علوي، حافظ إسماعيلي. (2010). الحجاج:

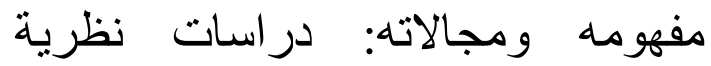

وتطبيقية في البلاغة الجديدة. إربد: عالم الكتب الحديث. ابن مالك، بدر الدين. (؟ْ). المصباح في الأدعاني و البيان و البديع. الجماميز: مكتبة الآداب ومطبعتها. المرزوقي، محمد ويحيى، الجيلاني بن الحاج.

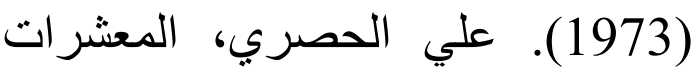
و اقتر اح القريح و اجنر اح الجريح. تونس: الثركة التونسية للتوزيع.

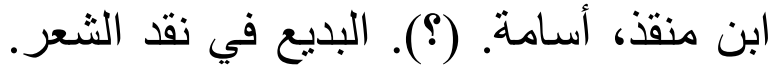

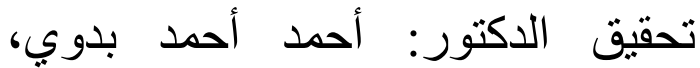

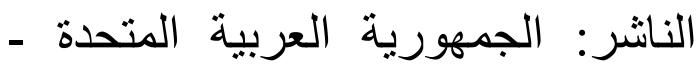
وزارة الثقافة والإرشاد القومي - الإقليم الجنوبي ـ الإدارة العامة للثقافة. 